\title{
Plant Population, Transplant Size, and Variety Effect on Transplanted Short-day Onion Production
}

\author{
George E. Boyhan ${ }^{1,5,9}$, Reid L. Torrance ${ }^{2,6}$, Jeff Cook $^{3,7}$, \\ Cliff Riner ${ }^{2,7}$, and C. Randell Hill ${ }^{4,8}$
}

ADDITIONAL INDEX WORDs. spring onions, nonstorage, bareroot, seedling, Vidalia, yield, seedstems, double bulbs, stand, spacing

Summary. Onions (Allium cepa) produced in southeastern Georgia's Vidaliagrowing region are primarily grown from on-farm-produced bareroot transplants, which are usually sown the end of September. These transplants are pulled midwinter (November-January) and are reset to their final spacing. This study was to evaluate transplant size and spacing effects on yield and quality of onions. Large transplants (260-280 g per 20 plants) generally produced the highest yield.

Medium transplant size in the range of 130 to $150 \mathrm{~g}$ per 20 plants produced satisfactory yield while maintaining low numbers of seedstems (flowering) and doubled bulbs, which are undesirable characteristics. Smaller transplant size (40-60 $\mathrm{g}$ per 20 plants) have reduced yields and lower numbers of seedstems and double bulbs. Increasing plant population from 31,680 to 110,880 plants/acre can increase yield. In addition, plant populations of 110,880 plants/acre can increase yields compared with 63,360 plants/acre (industry standard), but only when environmental conditions favor low seedstem numbers. Seedstems can be high because of specific varieties, high plant population, or more importantly, in years with environmental conditions that are conducive to their formation. 'Sweet Vidalia' was the only variety that had consistently reduced quality and high numbers of seedstems. 'Sweet Vidalia' has a propensity for high seedstem numbers, which may have influenced results with this variety. A complete fertilization program that included 133 or $183 \mathrm{lb} /$ acre nitrogen did not affect onion yield, regardless of variety or population density.

G eorgia's most important vegetable crop is the short-day sweet onion marketed as the Vidalia onion, which had a farm gate value over $\$ 125$ million in 2005 (Boatright and McKissick, 2006). This high value crop is produced from transplants produced on-farm in high-density plantings (Boyhan and Kelley, 2007). Onion seeds are sown in September at a rate of 800,000 to 2,000,000 seeds/acre. These plants are grown for 8 to 10 weeks, at which time they are harvested and trans-

\footnotetext{
${ }^{1}$ Department of Horticulture, University of Georgia, Southeast Georgia Extension Center, P.O. Box 8112, GSU, Statesboro, GA 30460

${ }^{2}$ Tattnall County Cooperative Extension Service, P.O Box 580, Reidsville, GA 30453

${ }^{3}$ Crawford County Cooperative Extension Service, P.O. Box 397, Butler, GA 31006

${ }^{4}$ Vidalia Onion and Vegetable Research Center, 8163 Highway 178, Lyons, GA 30436

${ }^{5}$ Associate Professor, Extension Horticulturist-Vegetables.

${ }^{6}$ County Extension Coordinator.

${ }^{7}$ County Extension Agent.

${ }^{8}$ Farm Superintendent.

${ }^{9}$ Corresponding author. E-mail: gboyhan@uga.edu.
}

planted to their final spacing of 60,000 to 80,000 plants/acre.

Transplant density, along with other factors, has been investigated in several studies with onion. For example, in Haryana, India, in a study comparing three different plant spacings and three different nitrogen $(\mathrm{N})$ rates, it was found that the highest density $(10 \times 5 \mathrm{~cm})$ had the smallest number of doubled bulbs and the thinnest necks compared with the medium $(10 \times 7.5 \mathrm{~cm})$ and low $(10 \times$ $10 \mathrm{~cm}$ ) densities (Gupta and Sharma, 2000). In addition, the high density had greater overall yields, but smaller bulbs. Finally, soluble solids and bolting (flowering) were not significantly affected. In a similar study, increasing plant population increased yield on clay or sandy soils (Abo-Zeid and Farghali, 1996). In addition, they found that bulb quality parameters (dry matter, bulb weight, and bulb diameter) were adversely affected at the high population density. Finally, Viloria et al. (2003) found increasing plant population from $12 \times 20 \mathrm{~cm}$ to $6 \times 20 \mathrm{~cm}$ spacing resulted in increased yield with maximum bulb fresh weight with a spacing of $10 \times$ $20 \mathrm{~cm}$.

In a study investigating rice rootknot nematode (Meloidogyne graminicola) and transplant age effect on yield and quality of onions, it was found that older transplants resulted in reduced yield along with reduced root and leaf weights (Gergon et al., 2002).

Herison et al. (1993) showed that increasing seedlings per cell in 200 -cell flats resulted in increased yield when transplanted without separating cell seedlings with long-day onions. In a similar study comparing greenhouse-grown to field-grown transplants, Russo (2004) found no yield difference between field-grown transplants and greenhouse-grown transplants produced in $58-\mathrm{cm}^{3}$ cells, but they had higher yields than onions produced in $36-\mathrm{cm}^{3}$ cells.

In an experiment with the shortday variety Granex 33, increasing row numbers per bed increased yield with a decrease in bulb size (Stoffella, 1996). In addition, increasing withinrow spacing decreased yield and increased bulb size. In Puerto Rico, with investigations of row spacing from 30 to $90 \mathrm{~cm}$ and two different fertilizer rates it was found that the closer spacing resulted in greater yield, regardless of the fertilizer rates (in $\mathrm{kg} \cdot \mathrm{ha}^{-1}$ : $111 \mathrm{~N}+48.4 \mathrm{P}+92.1 \mathrm{~K}$ or $222 \mathrm{~N}+96.9 \mathrm{P}+184.3 \mathrm{~K})$ (Mangual-Crespo et al., 1979). In

\begin{tabular}{llll}
\hline $\begin{array}{l}\text { Units } \\
\text { To convert U.S. to SI, } \\
\text { multiply by }\end{array}$ & U.S. unit & SI unit & $\begin{array}{l}\text { To convert SI to U.S., } \\
\text { multiply by }\end{array}$ \\
\hline 0.4047 & $\mathrm{acre}(\mathrm{s})$ & $\mathrm{ha}$ & $2.471 \mathrm{l}$ \\
0.3048 & $\mathrm{ft}$ & $\mathrm{m}$ & 3.2808 \\
0.0929 & $\mathrm{ft}^{2}$ & $\mathrm{~m}^{2}$ & 10.7639 \\
2.54 & inch(es $)_{\mathrm{cm}}$ & 0.3937 \\
16.3871 & inch & $\mathrm{cm}^{3}$ & 0.0610 \\
0.4536 & $\mathrm{lb}$ & $\mathrm{kg}^{3}$ & 2.2046 \\
1.1209 & $\mathrm{lb} / \mathrm{acre}$ & $\mathrm{kg} \cdot \mathrm{ha}^{-1}$ & 0.8922 \\
28.3495 & $\mathrm{oz}$ & $\mathrm{g}$ & 0.0353
\end{tabular}


the Treasure Valley of eastern Oregon and southwestern Idaho, a study of plant population and $\mathrm{N}$ rates showed that yield increased with increasing plant population from 185,000 to 370,000 plants/ha (Shock et al., 2004). In addition, there was a decrease in bulb size as the plant population increased. May et al. (2007) found similar results with decreasing bulb size as plant populations increased from 60 to 108 plants $/ \mathrm{m}^{2}$. This trend of increasing yield with higher plant densities and smaller bulb size appears to be consistent across many studies throughout the world.

Other aspects of transplant production have been investigated. For example, Sabota and Downes (1981) reported that onion yields were reduced when onion transplant roots were pruned and when smaller transplants were used.

The objectives of these experiments were to determine the effect of plant population on yield and quality, and to determine the effect of transplant size on yield and quality.

\section{Materials and methods}

All experiments were conducted at the Vidalia Onion and Vegetable Research Center in Lyons, GA (lat. $32^{\circ} 11^{\prime} \mathrm{N}$, long. $82^{\circ} 17^{\prime} \mathrm{W}$ ) on a Tifton soil (fine-loamy, siliceous, thermic Plinthic Paleudults).

All seeds were sown on highdensity plant beds according to University of Georgia Cooperative Extension Service recommendations (Boyhan and Kelley, 2007). Beds were prepared 6 -ft on-centers with four twin rows planted per bed with 12 inches between twin rows and $1 \mathrm{~cm}$ within row for each of the twin rows resulting in $\approx 60$ seeds per linear foot of row $(\approx 240$ seeds per linear foot of bed). All harvested transplants had $50 \%$ of their tops removed before transplanting as bareroot plants.

All seedlings were transplanted to a final spacing of 5.5 inches within rows and 12 inches between rows unless indicated otherwise. Four rows were planted on beds prepared on 6 - $\mathrm{ft}$ centers. Each experimental unit was $20 \mathrm{ft}$ of planted bed unless indicated otherwise and all experiments were randomized complete block designs with four replications.

All onions were harvested when judged mature for that variety.
Criteria for judging a variety mature was based on bulb size, weakness in the neck, and/or plants broken over at the neck. The tops and roots of harvested bulbs were immediately removed and the total yield was recorded for each experimental unit. Onions were then heat cured for $24 \mathrm{~h}$ at $95{ }^{\circ} \mathrm{F}$ and were then graded into jumbo- ( $\geq 3$ inches diameter) and medium- $(>2$ and $<3$ inches diameter $)$ sized onions according to U.S. Department of Agriculture standards (U.S. Department of Agriculture, 1995).

Transplant size study. Onion transplant size was evaluated over 3 years. In 2002, seeds of 'Granex 33' (Seminis Seed, St. Louis) were sown in high-density plant beds on 20 Sept. 2002. These plants were harvested on 18 Dec. 2002. They were then graded into three size classes; small (40-60 g per 20 plants), medium (130-150 g per 20 plants), and large (260-280 g per 20 plants). These plants were then transplanted to their final spacing with an experimental unit consisting of $5 \mathrm{ft}$ of planted bed with a 5 - $\mathrm{ft}$ within-row alley between plots. Seedstems (flowers) were counted for each plot on 25 Apr. 2003 and onions were harvested on 19 May 2003.

This experiment was repeated in the 2003-04 season with 'Sweet Vidalia' (Nunhems USA, Parma, ID) sown on 15 Sept. 2003. These transplants were harvested, graded into sizes, and transplanted on 3 Dec. 2003. Seedstems were counted on 22 Apr. 2004 and onions were harvested on 11 May 2004. The plot size in the $2003-04$ season was $10 \mathrm{ft}$ of planted bed with a $5-\mathrm{ft}$ within-row alley between plots.

Finally, in the 2004-05 season, varieties Granex 33 and Century (Seminis Seed) were sown on 21 Sept. 2004. These plants were harvested, graded into size classes, and transplanted on 22 Nov. 2004 as a complete factorial onto $10-\mathrm{ft}$ plots with variety and size class as the factors. Seedstems and doubles were counted for each experimental unit on 18 Apr. 2005. 'Granex 33' was harvested on 11 May 2005. 'Century' was harvested on 19 May 2005.

Transplant spacing study. Seeds of 'Sapelo Sweet' (Nunhems, Parma, ID) and 'Century' were sown on 21 Sept. 2004. These plants were transplanted to their final spacing on 6 Dec. 2004. The experiment was a factorial of two varieties and four plant spacings. One spacing consisted of plants 11 inches apart within-row spacing with 12 -inch between-row spacing. This resulted in $\approx 31,680$ plants/acre. A second low-density spacing consisted of 5.5-inch withinrow spacing with 24 -inch betweenrow spacing on a bed. Only two rows were planted on the bed, which resulted in $\approx 31,680$ plants/acre. A third spacing consisted of 5.5 -inch within-row spacing with 6 -inch between row spacing (seven rows on the bed), resulting in $\approx 110,880$ plants/ acre. The fourth and final spacing consisted of four rows on a bed with 5.5-inch within-row spacing and 12 -inch between-row spacing, which resulted in 63,360 plants/acre. This is the standard spacing at the research farm and is a common spacing among growers. Onions of 'Sapelo Sweet' were harvested on 11 May 2005 and 'Century' onions were harvested on 19 May 2005.

In the 2005-06 and 2006-07 seasons, complete factorial experiments were conducted with three varieties, two plant spacing arrangements, and two fertility programs. Seeds of 'WI-131' (Wannamaker Seed, St. Matthews, SC), 'Sweet Vidalia', and 'Georgia Boy' (D. Palmer Seed, Yuma, AZ) were sown on 19 Sept. 2005 and 18 Sept. 2006, respectively, and transplanted to their final spacing on 29 Nov. 2005 and 11 Dec. 2006, respectively.

The plant spacing treatments consisted of an within-row spacing of 5.5 inches with a between-row spacing of 12 inches, which resulted in 63,360 plants/acre and the second plant spacing had the same withinrow spacing of 5.5 inches, but the between row spacing was 6 inches, which resulted in 110,880 plants/ acre (seven rows on the bed).

Both fertility treatments in the 2005-06 and 2006-07 seasons received a standard fertilizer program for onion production in this region (Boyhan et al., 2001). This consisted of $400 \mathrm{lb} /$ acre of $5 \mathrm{~N}-4.4 \mathrm{P}-12.4 \mathrm{~K}$ with $9 \%$ sulfur (S) applied on 14 Nov. in 2005 and 31 Oct. in 2006, followed by $150 \mathrm{lb} /$ acre diammonium phosphate $(18 \mathrm{~N}-20.1 \mathrm{P}-0 \mathrm{~K})$ applied on 20 Dec. in 2005 and 6 Dec. in 2006. On 6 and 17 Jan. 2006 
(3 and 13 Jan. 2007), $200 \mathrm{lb} /$ acre of $6 \mathrm{~N}-5.2 \mathrm{P}-14.9 \mathrm{~K}-4 \mathrm{~S}$ was applied. Finally, on 1 and 15 Feb. 2006 (6 and 19 Feb. 2007), 200 lb/acre calcium nitrate was applied. This resulted in $133 \mathrm{~N}-68.5 \mathrm{P}-109.6 \mathrm{~K}-52 \mathrm{~S}$. The second fertility treatment had an additional $50 \mathrm{lb}$ of $\mathrm{N}$ applied as $323 \mathrm{lb} /$ acre calcium nitrate, which was applied on 23 Feb. in 2006 and 27 Feb. in 2007.

Onions of 'WI-131' were harvested on 12 Apr. 2006 and 13 Apr. 2007. 'Sweet Vidalia' and 'Georgia Boy' were harvested on 27 Apr. 2006. In 2007, 'Sweet Vidalia' was harvested on 24 Apr. 2007 and 'Georgia Boy' was harvested on 27 Apr. 2007.

Data from all studies were analyzed with Excel (version 11.3.5; Microsoft Corp., Redmond, WA) and Stata (version 10.0; StataCorp, College Station, TX). Count data (seedstems and doubles) were transformed with square root $(\mathrm{x}+\mathrm{l})$ before analyses and reported values were back-transformed to their original units.

\section{Results}

Transplant size study. There were no differences in total yield in 2003 between onion transplant sizes (Table 1). In 2004, however, medium and large onion transplants had significantly greater yield than small transplants. There was no difference in jumbo yield between transplant sizes in 2003 or 2004 . Medium yields were unaffected in 2003 , but were significantly greater for large transplants in 2004. Large and medium transplants resulted in significantly greater numbers of seedstems compared with small transplants in 2003. In 2004, the number of seedstems with large transplants was significantly greater than with small or medium transplants.

In the 2004-05 season, total yield was unaffected by variety, but was affected by transplant size and there was an interaction effect between variety and transplant size (Table 2). The interaction showed that significant differences between varieties occurred with the mediumand large-size transplants, but not the small transplants. Total yield was significantly greater with large transplants compared with medium and small transplants. In addition, total yield was greater with medium-sized

Table 1. Size-graded transplants of short-day onions effect on yield, graded yield, and number of seedstems for the 2002-03 and 2003-04 seasons in Lyons, GA.

\begin{tabular}{|c|c|c|c|c|}
\hline \multirow[b]{3}{*}{ Graded size ${ }^{x}$} & \multicolumn{4}{|c|}{$2003^{z}$} \\
\hline & Total yield & Jumbo yield $^{y}$ & Medium yieldy & \multirow{2}{*}{$\begin{array}{c}\text { Seedstems } \\
\text { (no./plot) }\end{array}$} \\
\hline & \multicolumn{3}{|c|}{$(\mathrm{lb} / \text { acre })^{\mathrm{w}}$} & \\
\hline Small & 24,829 & 9,583 & 10,164 & 4 \\
\hline Medium & 27,443 & 13,504 & 10,745 & 14 \\
\hline Large & 25,700 & 11,471 & 9,438 & 19 \\
\hline \multirow[t]{2}{*}{$P>\mathrm{F}$} & 0.835 & 0.313 & 0.777 & 0.039 \\
\hline & \multicolumn{4}{|c|}{$2004^{z}$} \\
\hline Small & 32,634 & 26,390 & 726 & 2 \\
\hline Medium & 45,847 & 32,924 & 962 & 6 \\
\hline Large & 46,537 & 28,496 & 2,160 & 22 \\
\hline$P>\mathrm{F}$ & 0.002 & 0.137 & 0.030 & 0.000 \\
\hline
\end{tabular}

'Granex 33' was used in 2003 with 5 -ft plots on 6 -ft centers ( 1 seedstem $/$ plot $=1452 /$ acre $=3588 / \mathrm{ha})$. 'Sweet Vidalia' was used in 2004 with 10 -ft plots on 6 -ft centers $(1$ seedstem $/$ plot $=726 /$ acre $=1794 /$ ha $)$; $\mathrm{l} \mathrm{ft}=0.3048 \mathrm{~m}$.

y Jumbo $\geq 3$ inches diameter, medium $\geq 2$ inches and $<3$ inches diameter; 1 inch $=2.54 \mathrm{~cm}$.

${ }^{\times}$Small $=40-60 \mathrm{~g}$ per 20 plants, medium $=130-150 \mathrm{~g}$ per 20 plants, large $=260-280 \mathrm{~g}$ per 20 plants; $1 \mathrm{~g}=$ $0.0353 \mathrm{oz}$.

${ }^{\mathrm{w}} \mathrm{l} \mathrm{lb} / \mathrm{acre}=1.1209 \mathrm{~kg} \cdot \mathrm{ha}^{-1}$.

Table 2. Effect of transplant size on yield, graded yield, number of seedstems, and doubles for short-day onions, 2004-05 season in Lyons, GA.

\begin{tabular}{|c|c|c|c|c|c|}
\hline & Total yield & $\begin{array}{l}\text { Jumbo } \\
\text { yield }^{z}\end{array}$ & $\begin{array}{l}\text { Medium } \\
\text { yield }^{\mathrm{z}}\end{array}$ & Seedstems & Doubles \\
\hline & \multicolumn{3}{|c|}{$(\mathrm{lb} / \mathrm{acre})^{\mathrm{y}}$} & \multicolumn{2}{|c|}{$(\text { no. } / \text { plot })^{x}$} \\
\hline \multicolumn{6}{|l|}{ Variety } \\
\hline Granex 33 & 41,194 & 34,812 & 1,549 & 0.4 & 2.6 \\
\hline Century & 43,493 & 24,115 & 1,186 & 0.1 & 0.7 \\
\hline \multicolumn{6}{|l|}{ Transplant size ${ }^{\mathrm{w}}$} \\
\hline Small & 24,403 & 15,373 & 1,869 & 0.0 & 0.2 \\
\hline Medium & 42,825 & 31,418 & 1,488 & 0.0 & 0.8 \\
\hline Large & 59,804 & 41,600 & 744 & 1.1 & 4.5 \\
\hline \multicolumn{6}{|l|}{ Probability } \\
\hline Variety & 0.329 & 0.000 & 0.047 & 0.197 & 0.001 \\
\hline Transplant size & 0.000 & 0.000 & 0.000 & 0.005 & 0.000 \\
\hline $\begin{array}{l}\text { Variety } \times \text { transplant } \\
\text { size }\end{array}$ & 0.010 & 0.000 & 0.984 & 0.196 & 0.000 \\
\hline $\operatorname{LSD}(0.05)^{\mathrm{v}}$ & 6,921 & 5,707 & 509 & 0.9 & 0.8 \\
\hline
\end{tabular}

transplants compared with small transplants. Jumbo yields had significant differences based on variety and transplant size, as well as there being a variety by transplant size interaction. The interaction effect on jumbo indicated that variety differences only occurred with the large transplants, with no variety differences if small or medium transplant sizes were used. Large transplant size resulted in greater jumbo yields compared with medium or small transplant size. Finally, medium transplants produced more jumbo yield compared with small transplants. Medium onion yields were affected by variety and transplant size. There was no interaction effect for medium yield. 'Granex 33' produced more mediumsized onions than 'Century'. Finally, small transplants produced more medium-sized onions than large transplants and medium transplants produced more medium-sized onions than large transplants.

The number of seedstems was greater with large transplants compared with medium or small transplants and was unaffected by variety. The number of doubled bulb was significantly greater with 'Granex 
33' than 'Century'. In addition, large transplants produced more doubles than medium or small transplants. Because of the variety by transplant size interaction, medium transplants resulted in more doubles than small transplants, but with 'Granex 33' only.

Transplant SPaCing study. In the 2004-05 season, variety and plant density had an effect on total yield (Table 3). 'Century' had a higher total yield than 'Sapelo Sweet'. The standard population density and the high-density treatment had higher total yields than either low-density treatments.

There was a population by variety interaction for jumbo yields, therefore variety results are presented separately for the different plant population treatments (Table 3 ). The high-density plant population of 'Century' had greater jumbo yields than either of the low-density plant populations. The standard plant population of 'Century' also had greater jumbo yields than either of the lowdensity plant population treatments. The standard plant population treatment of 'Sapelo Sweet' had greater jumbo yields than the high-density plant population or either low-density treatments.

There was a variety by population density interaction for medium yields, therefore the variety results are presented separately (Table 3 ). The

Table 3. Variety and population density of short-day onions effect on total and graded yield, 2004-05 season in Lyons, GA.

\begin{tabular}{|c|c|c|c|c|c|}
\hline \multirow[b]{2}{*}{ Treatments } & Total yield & \multicolumn{2}{|c|}{ Jumbo yield $^{\mathrm{z}}$} & \multicolumn{2}{|c|}{ Medium yield ${ }^{\mathrm{z}}$} \\
\hline & \multicolumn{5}{|c|}{$(\mathrm{lb} / \text { acre })^{\mathrm{y}}$} \\
\hline \multicolumn{6}{|l|}{ Variety } \\
\hline Century & 44,331 & & & & \\
\hline Sapelo Sweet & 37,761 & & & & \\
\hline Population density ${ }^{x}$ & \multicolumn{3}{|c|}{ 'Century' 'S } & 'Century & pelo Sw \\
\hline Low density 1 & 31,658 & 16,997 & 25,682 & 635 & 1,035 \\
\hline Low density 2 & 31,259 & 23,522 & 23,014 & 526 & 1,779 \\
\hline High density & 54,069 & 42,326 & 26,681 & 4,755 & 11,598 \\
\hline Standard & 47,199 & 33,886 & 33,215 & 1,434 & 5,209 \\
\hline \multicolumn{6}{|l|}{ Probability } \\
\hline Variety & 0.050 & \multicolumn{2}{|c|}{0.322} & \multicolumn{2}{|c|}{0.000} \\
\hline Population & 0.000 & \multicolumn{2}{|c|}{0.000} & \multicolumn{2}{|c|}{0.000} \\
\hline Variety $\times$ population & 0.317 & \multicolumn{2}{|c|}{0.003} & \multicolumn{2}{|c|}{0.007} \\
\hline $\operatorname{LSD}(0.05)^{\mathrm{w}}$ & 10,890 & 8,966 & 4,719 & 1,016 & 3,086 \\
\hline
\end{tabular}

${ }^{\mathrm{Z}}$ Jumbo $\geq 3$ inches diameter, medium $\geq 2$ and $<3$ inches diameter; 1 inch $=2.54 \mathrm{~cm}$.

y $1 \mathrm{lb} /$ acre $=1.1209 \mathrm{~kg} \cdot \mathrm{ha}^{-1}$

'Low density $1=11$ inches within rows and 12 inches between rows $[31,680$ plants $/$ acre $(78,283$ plants $/$ ha $)]$, low density $2=5.5$ inches within rows and 24 inches between rows $[31,680$ plants/acre $(78,283$ plants $/$ ha $)]$, high density $=5.5$ inches within rows and 6 inches between rows $[110,880$ plants $/$ acre $(273,990$ plants $/$ ha $)]$, standard $=$ 5.5 inches within rows and 12 inches between rows [63,360 plants/acre (156,566 plants/ha)].

"Fisher's protected least significant difference at $P \leq 0.05$

high-density treatment with 'Century' had greater medium yields than the standard plant population or either of the low-density treatments. For 'Sapelo Sweet', the high-density plant population had greater medium yield than the standard or either low-density plant populations.

In the 2005-06 and 2006-07 seasons when variety, plant population, and fertility were evaluated, total ield had a variety by year and a vity by year interaction for jumbo yields, but for ming yields, there was only a population density by year interaction. Because of the interactions, the data are presented by year (Table 5). Fertility, whether 133 or $183 \mathrm{lb} /$ acre $\mathrm{N}$, had effect on yield and had no interaction effect with variety or population density (Table 4).

The number of seedstem data collected in 2006-07 had a variety by population density interaction, thus, these results are presented separately (Table 5). The number of doubles was significantly affected by variety (Table 4). 'WI-131' had a greater number of doubles compared with 'Sweet Vidalia' or 'Georgia Boy'. Neither plant population nor fertility affected double numbers.

In the 2005-06 season, variety did not affect total yield, but population density did, with the high-density plant population yielding more than the standard population (Table 5). In the 2006-07 season, there was a significant variety by population density interaction, thus, these results are presented separately for each variety (Table 5). There was a significantly higher total yield for 'WI-131' and 'Georgia Boy', with the high-density planting compared with the standard, but there was no such effect for 'Sweet Vidalia'.

Jumbo yields were significantly greater with the high population density compared with the standard population in the 2005-06 season. In the 2006-07 season, there was a significant variety by population density interaction. Neither 'WI-131' nor 'Georgia Boy' had differences in jumbo yield due to plant population density. 'Sweet Vidalia' did have a significant difference based on plant population, with the standard population yielding more than the highdensity planting. Population density had a significant effect on medium yields in the 2005-06 and 2006-07 seasons, with the high-density treatment yielding more than the standard plant population.

Finally, seedstems were significantly greater with the high-density population for 'WI-131' and 'Sweet Vidalia' (Table 5). 'Georgia Boy' had similar low numbers of seedstems, regardless of the plant population density.

\section{Discussion}

The 2003-04 season had particularly high numbers of seedstems and doubles (Boyhan et al., 2004). Seedstems are usually greater when cool temperatures $\left(<50{ }^{\circ} \mathrm{F}\right)$ occur late in the season (March-April) when plants have sufficient leaf numbers to respond to these conditions and enter a sexual phase (Brewster, 1994). Doubles also respond to environmental effects because some years are worse than others for this condition, although it is not understood why this is so. Seedstems and doubles were not nearly as bad overall in the 200405 season, therefore the numbers reported this year are more reflective of the treatment effects rather than the environmental effects.

Transplant size can be an important factor in onion performance. Generally, larger transplants produce greater yield, but also higher numbers of seedstems and doubles. These 
Table 4. Variety, spacing, and fertility effect on yield, graded yield, seedstems, and doubles of short-day onions in the 2005-06 and 2006-07 seasons in Lyons, GA.

\begin{tabular}{|c|c|c|c|c|c|}
\hline \multirow[b]{2}{*}{ Treatments } & $\begin{array}{l}\text { Total } \\
\text { yield }\end{array}$ & $\begin{array}{l}\text { Jumbo } \\
\text { yield }^{z}\end{array}$ & $\begin{array}{l}\text { Medium } \\
\text { yield }^{\mathrm{z}}\end{array}$ & \multirow{2}{*}{\multicolumn{2}{|c|}{$\frac{\text { Seedstems }^{\mathrm{y}} \text { Doubles }^{\mathrm{y}}}{(\text { No./plot })^{\mathrm{w}}}$}} \\
\hline & \multicolumn{3}{|c|}{$(\text { lb/acre })^{x}$} & & \\
\hline \multicolumn{6}{|l|}{ Variety } \\
\hline WI-131 & 54,545 & 37,342 & 4,439 & 13.7 & 10.9 \\
\hline Sweet Vidalia & 48,958 & 30,164 & 3,742 & 63.1 & 5.1 \\
\hline Georgia Boy & 51,889 & 36,325 & 3,361 & 3.0 & 5.6 \\
\hline \multicolumn{6}{|l|}{ Population density ${ }^{\mathrm{v}}$} \\
\hline Standard & 46,694 & 33,333 & 1,544 & 12.7 & 6.2 \\
\hline High & 56,901 & 35,888 & 6,150 & 29.6 & 7.8 \\
\hline \multicolumn{6}{|l|}{ Fertility $^{\mathrm{u}}$} \\
\hline Standard & 51,490 & 34,406 & 3,631 & 20.4 & 6.5 \\
\hline High & 52,105 & 34,815 & 4,063 & 20.2 & 7.5 \\
\hline \multicolumn{6}{|l|}{ Probability } \\
\hline Variety & 0.512 & 0.492 & 0.136 & 0.000 & 0.000 \\
\hline Population density & 0.143 & 0.639 & 0.264 & 0.000 & 0.114 \\
\hline Fertility & 0.772 & 0.791 & 0.256 & 0.955 & 0.307 \\
\hline $\begin{array}{l}\text { Variety } \times \text { population } \\
\text { density }\end{array}$ & 0.228 & 0.415 & 0.230 & 0.003 & 0.389 \\
\hline Variety $\times$ fertility & 0.280 & 0.282 & 0.918 & 0.762 & 0.558 \\
\hline Population density $\times$ fertility & 0.997 & 0.750 & 0.150 & 0.858 & 0.509 \\
\hline $\begin{array}{l}\text { Variety } \times \text { population } \\
\text { density } \times \text { fertility }\end{array}$ & 0.342 & 0.738 & 0.403 & 0.639 & 0.935 \\
\hline Year & 0.008 & 0.035 & 0.004 & - & - \\
\hline Variety $\times$ year & 0.007 & 0.000 & 0.238 & - & - \\
\hline Population density $\times$ year & 0.046 & 0.000 & 0.000 & - & - \\
\hline Fertility $\times$ year & 0.144 & 0.130 & 0.308 & - & - \\
\hline $\operatorname{LSD}(0.05)^{\mathrm{t}}$ & & & & 1.0 & 0.7 \\
\hline
\end{tabular}

${ }^{\mathrm{z}}$ Jumbo $\geq 3$ inches diameter, medium $\geq 2$ and $<3$ inches diameter; 1 inch $=2.54 \mathrm{~cm}$.

${ }^{y}$ Data collected in 2007 only

${ }^{x} 1 \mathrm{lb} /$ acre $=1.1209 \mathrm{~kg} \cdot \mathrm{ha}^{-1}$.

"Plot size was $20 \mathrm{ft}$ on 6 - $\mathrm{ft}$ centers $(1$ seedstem per plot $=363 /$ acre $=897 / \mathrm{ha}) ; 1 \mathrm{ft}=0.3048 \mathrm{~m}$.

${ }^{v}$ Standard $=12$ inches between rows and 5.5 inches within rows $[63,360$ plants/acre $(156,566$ plants $/$ ha $)]$, high $=6$ inches between rows and 5.5 inches within rows [110,880 plants/acre (273,990 plants/ha)]

"Standard $=133 \mathrm{lb} /$ acre nitrogen $(\mathrm{N})+69 \mathrm{lb} /$ acre phosphorus $(\mathrm{P})+110 \mathrm{lb} /$ acre potassium $(\mathrm{K})+52 \mathrm{lb} / \mathrm{acre}$ sulfur $(S)$, high $=183 \mathrm{lb} /$ acre $\mathrm{N}+69 \mathrm{lb} /$ acre $\mathrm{P}+110 \mathrm{~K}+52 \mathrm{lb} /$ acre $S$.

tFisher's protected least significant difference at $P \leq 0.05$.

results are mirrored in Russo's (2004) study where greenhouse-grown transplants in $58-\mathrm{cm}^{3}$ cells produced greater yields than those produced in $36-\mathrm{cm}^{3}$ cells, presumably because of larger starting fresh weights with the former. Gergon et al. (2002), on the other hand, had lower yields with older transplants, which would presumably be larger. This may have occurred because older transplants are more stressed and more apt to enter a sexual phase as occurred in our study.

In our study, the increase in yield with larger transplants is a function of starting size and survivability. In fields where onions are from small transplants, there are usually greater losses through stand loss, as onions are more easily killed by diseases, especially during periods of slow growth with colder winter temperatures.
Large transplants in most years would perform well; however, in years favoring seedstem formation, they would have much higher losses. This is reflected in comparing the percentage of marketable yield for medium-sized transplants to large transplants in 2004 , a year with particularly large numbers of seedstems and doubles. The percentage of marketable onions for medium-sized transplants was $72 \%$ and for large transplants was $66 \%$. Growers generally want to plant a transplant that is $\approx 1 \mathrm{~cm}$ in diameter at the base, which corresponds to the medium-sized transplants in this study. This seems to be the best balance for maximizing yield, while minimizing seedstems.

The initial experiment in 200405 evaluating population density effect on yield indicated that higher population density would have a positive effect on total yield and at least with one variety, 'Century', a positive effect on jumbo yields. This increase in yield also carried over to the medium class for both of these varieties, however, this is not as important because growers typically wish to sell the bulk of their onions as jumbo or larger.

Surprisingly, population density was not a significant effect on yield over the two seasons, 2005-06 and 2006-07. However, with year as a random effect, the denominator in an $F$ test is a much larger value and therefore the test is more conservative. However, there was a yield by year interaction effect and when seasons are looked at individually, both seasons had total yields higher at the higher plant density. This is supported by several previous studies (Mangual-Crespo et al., 1979; May et al., 2007; Shock et al., 2004; Stoffella, 1996). In the 2006-07 season, there was an additional interaction effect between variety and population density. 'WI-131' and 'Georgia Boy' had greater total yields with the high-density population, but 'Sweet Vidalia' did not. This was due to the high number of seedstems 'Sweet Vidalia' had, which has become a hallmark of this variety. In the last 3 of 4 years, 'Sweet Vidalia' has been trialed in the Vidalia-growing region, it has had the highest number of seedstems of all varieties tested.

Jumbo yields were also mixed with the high-density treatment having greater yields in the 2005-06 season, but in the 2006-07 season, this was not the case. The only difference in jumbo yields among the varieties in the 2006-07 season was with 'Sweet Vidalia', which had greater jumbo yields with the standard population density. This was probably due to the high number of seedstems with 'Sweet Vidalia' in the high-density planting.

Results of this study generally reflected results of previous studies, however, differences such as the increase in jumbo yields in 2006 with the high-density planting compared with the standard and no difference in 2007 probably reflect the much lower plant populations used in the Vidalia-growing region compared with other studies where plant populations of over 100,000 are used. The increase of medium-sized onions 
Table 5. Yield, and graded yield by year for the 2005-06 and 2006-07 seasons for significant treatment by year interactions and for seedstems with a population density by variety interaction for the 2006-07 season of short-day onions grown in Lyons, GA.

\begin{tabular}{|c|c|c|c|c|c|c|c|}
\hline \multirow[b]{3}{*}{ Treatments } & \multicolumn{2}{|c|}{$\begin{array}{l}\text { Total } \\
\text { yield }\end{array}$} & \multirow{2}{*}{\multicolumn{2}{|c|}{$\begin{array}{c}\begin{array}{c}\text { Jumbo } \\
\text { yield }^{z}\end{array} \\
(\text { lb } / \text { acre })^{x}\end{array}$}} & \multicolumn{2}{|c|}{$\begin{array}{c}\text { Medium } \\
\text { yield }^{\mathbf{z}}\end{array}$} & \multirow{3}{*}{$\begin{array}{l}\text { Seedstems } \\
{\text { (no./plot })^{\mathrm{w}}}^{\mathrm{w}}\end{array}$} \\
\hline & & & & & & & \\
\hline & 2006 & 2007 & 2006 & 2007 & 2006 & 2007 & \\
\hline \multicolumn{8}{|l|}{ Variety } \\
\hline WI-131 & 59,530 & 49,561 & 37,455 & 37,230 & & & \\
\hline Sweet Vidalia & 59,625 & 38,292 & 37,616 & 22,712 & & & \\
\hline Georgia Boy & 59,146 & 44,631 & 38,244 & 34,406 & & & \\
\hline \multicolumn{8}{|l|}{ Population density ${ }^{\mathrm{v}}$} \\
\hline Standard & 53,164 & 40,223 & 34,491 & 32,175 & 487 & 2,602 & \\
\hline High & 65,703 & 48,099 & 41,052 & 30,723 & 3,064 & 9,235 & \\
\hline \multicolumn{8}{|l|}{ Population density ${ }^{v}$} \\
\hline \multicolumn{8}{|l|}{ WI-131 } \\
\hline Standard & & 42,680 & & 38,129 & & & 6.9 \\
\hline High & & 56,442 & & 36,332 & & & 22.6 \\
\hline \multicolumn{8}{|l|}{ Sweet Vidalia } \\
\hline Standard & & 37,865 & & 25,328 & & & 42.4 \\
\hline High & & 38,718 & & 20,097 & & & 87.7 \\
\hline \multicolumn{8}{|l|}{ Georgia Boy } \\
\hline Standard & & 40,125 & & 33,069 & & & 1.3 \\
\hline High & & 49,137 & & 35,742 & & & 3.9 \\
\hline \multicolumn{8}{|l|}{ Probability } \\
\hline Variety & 0.980 & 0.000 & 0.907 & 0.000 & & & \\
\hline Population density & 0.000 & 0.000 & 0.000 & 0.138 & 0.000 & 0.000 & \\
\hline $\begin{array}{l}\text { Variety } \times \text { population } \\
\text { density }\end{array}$ & 0.739 & 0.008 & 0.455 & 0.007 & & & \\
\hline \multicolumn{8}{|l|}{ Population density } \\
\hline WI-131 & & 0.003 & & 0.278 & & & 0.000 \\
\hline Sweet Vidalia & & 0.745 & & 0.018 & & & 0.000 \\
\hline Georgia Boy & & 0.000 & & 0.075 & & & 0.123 \\
\hline
\end{tabular}

${ }^{\text {ZJumbo }} \geq 3$ inches diameter, medium $\geq 2$ and $<3$ inches diameter; 1 inch $=2.54 \mathrm{~cm}$.

y Data collected in 2007 only.

${ }^{x} \mathrm{l} \mathrm{lb} /$ acre $=1.1209 \mathrm{~kg} \cdot \mathrm{ha}^{-1}$.

wPlot size was $20 \mathrm{ft}$ on 6 -ft centers ( 1 seedstem per plot $=363 /$ acre $=897 / \mathrm{ha}$ ); $1 \mathrm{ft}=0.3048 \mathrm{~m}$.

"Standard $=12$ inches between rows and 5.5 inches within rows $[63,360$ plants $/$ acre $(156,566$ plants $/$ ha $)]$, high $=$ 6 inches between rows and 5.5 inches within rows [ 110,880 plants/acre $(273,990$ plants/ha $)]$.

with higher plant populations does more closely mirror the results of other studies where smaller onions are produced with higher plant populations.

The number of seedstems with 'WI-131' at the high-density population was significantly greater, with an average of 22.6 seedstems/plot compared with 6.9 seedstems/plot at the standard population. This was also the case with 'Sweet Vidalia'. In both of these cases, this was probably an important contributing factor to there not being differences in jumbo yields between the different population densities. Medium yields were higher with the higher plant population, regardless of year. When you increase the plant population, the crowding increases competition for resources and reduces the space for bulb expansion, resulting in more medium yields.

The $133 \mathrm{lb} /$ acre $\mathrm{N}$ rate is within the standard range (125-150 lb/ acre) recommended for onions in southeastern Georgia (Boyhan and Kelley, 2007). The higher $\mathrm{N}$ fertility treatment $(183 \mathrm{lb} /$ acre $)$ was included to determine whether an $\mathrm{N}$ rate has a positive effect at higher plant populations. This was not the case, indicating that even with high plant populations, current recommendations should be adequate for onion production.

In conclusion, transplants graded into the medium-size class had good yields, while minimizing the number of seedstems, particularly in years where environmental conditions favor seedstem formation. In addition, population density can have a significant effect on yield, but varieties with a high propensity for seedstems or in years conducive to seedstem formation, the increase in yields may not occur particularly with jumbo. Jumbo yields are not just a function of variety or cultural practice, but are also the subjective screening that occurs during the grading process. Onions clipped with seedstems would be graded out as culls because of hard necks, causing a reduction in jumbo yields.

\section{Literature cited}

Abo-Zeid, M.I. and M.A. Farghali. 1996. Potassium fertilization and plant density effects on onion grown in different soils. Assiut J. Agr. Sci. 27:33-45.

Boatright, S.R. and J.C. McKissick. 2006. 2005 Georgia farm gate value report. Coop. Ext. Serv. Area Rpt. AR-06-01.

Boyhan, G.E. and Kelley, W.T. 2007. Onion production guide. Univ. Georgia Coop. Ext. Serv. Bul. 1198.

Boyhan, G.E., D.M. Granberry, and W.T. Kelley. 2001. Onion production guide. Univ. Georgia Bul. 1198.

Boyhan, G., R. Torrance, R. Blackley, J. Cook, R. Hill, and J. Paulk. 2004. Vidalia onion variety trials 2003-2004. 2004 Georgia Onion Res.-Ext. Rpt. No. 32004:1-4.

Brewster, J.L. 1994. Crop production science in horticulture. CAB Intl., Wallingford, UK.

Gergon, E.B., S.A. Miller, J.M. Halbrendt, and R.G. Davide. 2002. Effect of rice root-knot nematode on growth and yield of Yellow Granex onion. Plant Dis. 86: 1339-1344.

Gupta, R.P. and V.P. Sharma. 2000. Effect of different spacings and levels of nitrogen for production of export quality onion bulbs planted on raised bed. Nwsl. Natl. Hort. Res. Dev. Foundation 20: 13-16.

Herison, C., J.G. Masabni, and B.H. Zandstra. 1993. Increasing seedling density, age and nitrogen fertilization increases onion yield. HortScience 28: 23-25.

Mangual-Crespo, G., C.T. Ramirez, and E. Orengo. 1979. Effect of plant spacing and fertilizer levels on yield and dry bulb weight of onion cv. Texas Grano 502. J. Agr. Univ. Puerto Rico 63:417-422.

May, A., A.B. Cecilio-Filho, D.R. de Q. Porto, P.F. Vargas, and J.C. Barbosa. 2007. Plant density and nitrogen and 
potassium fertilization rates on yield of onion hybrids. Horticultura Brasileira 25: 53-59.

Russo, V.M. 2004. Greenhouse-grown transplants as an alternative to bare-root transplants for onion. HortScience 39: 1267-1271.

Sabota, C.M. and J.D. Downes. 1981. Onion growth and yield in relation to transplant pruning, size, spacing, and depth of planting. HortScience 16: 533-535.

Shock, C.C., E.B.G. Feibert, and L.D. Saunders. 2004. Plant population and nitrogen fertilization for subsurface drip-irrigated onion. HortScience 39:1722-1727.

Stoffella, P.J. 1996. Planting arrangement and density of transplants influence sweet Spanish onion yields and bulb size. HortScience 31:1129-1130.
U.S. Department of Agriculture. 1995. United States standards for grades of Bermuda-Granex-Grano type onions. U.S. Dept. Agr. Rpt., Washington, DC.

Viloria, A., L. Arteaga, L. Díaz, and D. Delgado. 2003. Effect of N-P-K fertilization and planting distance on onion (Allium cepa L.) yield. Bioagro 15:129-133. 